\title{
Prevalence of Suicidal Ideation and Suicide Attempts Among Refugees: A Meta-analysis
}

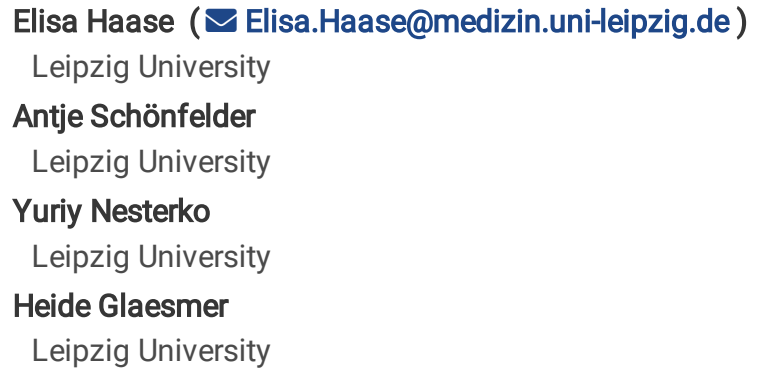

\section{Research Article}

Keywords: suicidal ideation, suicide attempts, refugees, mental health, asylum-seekers, prevalence

Posted Date: September 16th, 2021

DOI: https://doi.org/10.21203/rs.3.rs-732316/v1

License: (c) (i) This work is licensed under a Creative Commons Attribution 4.0 International License. Read Full License

Version of Record: A version of this preprint was published at BMC Public Health on April 1st, 2022. See the published version at https://doi.org/10.1186/s12889-022-13029-8. 


\section{Abstract}

Background: Suicidal ideation and attempts are one of the most serious mental health problems affecting refugees. Risk factors such as mental disorders, low socio-economic status, and stressful life events all contribute to making refugees a high-risk group. For this reason, this meta-analysis aims to investigate the prevalence of suicidal ideation and attempts among refugees in non-clinical populations.

Method: All studies published in English up through August 2020 were considered for the analysis. We searched four databases for articles reporting (period) prevalence rates of suicidal ideation and attempts.

Results: Of 294 hits, 11 publications met the inclusion criteria. Overall prevalence rates were calculated using Rstudio. The overall period prevalence of suicidal ideation was $20.5 \%$ (Cl: $\left.0.11-0.32,1^{2}=98 \%, n=8\right), 22.3 \%\left(\mathrm{Cl}: 0.10-0.38,1^{2}=97 \%, n=5\right)$ for women, and $23.3 \%$ for men (Cl: $\left.0.13-0.35, I^{2}=87 \%, n=3\right)$. Suicide attempts had an overall prevalence of $0.57 \%\left(\mathrm{Cl}: 0.00-0.02, I^{2}=81 \%, n=4\right)$.

Conclusion: There is a great lack of epidemiological studies on suicidal ideation and attempts among refugees. The high prevalence of suicidal ideation indicates the existence of heavy psychological burden among this population. The prevalence of suicide attempts is similar to that in non-refugee populations. In addition, the results underline the need for systematic and standardized assessment and treatment of suicidal ideation and attempts.

\section{Background}

Approximately 800,000 people die by suicide each year, making suicide one of the leading causes of death worldwide [1]. Thus, suicide is a global and complex public health problem. There are distinct differences in the development of suicidal ideation and attempts associated with gender, age, geographic region, and socio-political conditions [2]. People who live in war zones, experience armed conflicts, persecution, displacement, traumatization, social isolation, and somatic and mental illnesses are particularly at risk [1]. Forced displacement and seeking asylum often involve dangerous travel, separation from family and friends, inhumane living conditions, and fear of being detained and dying. In addition, post-migration stressors such as perceived discrimination, restricted access to health care, education and/or work, etc. are further problems refugees face after they arrived in secure host countries [3]. Accordingly, refugees and/or asylum-seekers are at high risk for any kind of suicidal ideation and attempts before, during, and/or after flight [4].

Due to the multitude of stressful events that most refugees experience as a result of the process of leaving their homes, the likelihood of them developing mental disorders is substantially elevated. The most common disorders are depression, anxiety disorders, post-traumatic stress disorder, and somatization disorders [5-9]. Individuals with mental disorders and stressful life events are more likely to suffer from suicidal ideation and to attempt suicide.

\section{Suicidal ideation}

The global lifetime prevalence of suicidal ideation is $9.2 \%$ across 17 countries in Africa, Asia and the Pacific, North America, Europe, and the Middle East; $n=84,850$ ) [10], 3.1-12.0\% in developing countries, and 3.0\%-15.9\% in developed countries. Twelve-month prevalence estimations across 21 countries are $2.0 \%$ for developed countries (e.g. France, US, Germany, Israel, Japan) and 2.1\% for developing countries (e.g. Brazil, Bulgaria, India, Lebanon, Nigeria, South Africa) $(n=108,705)$ [11]. In a review of 86 studies worldwide, Liu et al. [12] showed that the twelve-month prevalence of passive suicidal ideation was $5.8 \%$ and lifetime prevalence was $10.6 \%$ in the general population.

General risk factors for suicidal ideation include: previous suicidal ideation, feelings of hopelessness, depression, anxiety, abusive experiences of any kind [13], somatic pain [14], female gender [10, 15].

Prevalence data on suicidal ideation and attempts in refugee populations are scarce. Studies on suicidal ideation show significantly higher rates among refugees compared to non-refugee populations. In a study on suicidal ideation (experienced in the month before responding to the survey) among refugees from Libya, Sudan, Congo, etc., in Nigeria, $27.3 \%(n=444)$ of refugee participants reported suicidal ideation, a significant difference compared to $17.3 \%(n=527)$ of that host country's residents $(n=527)$ [16]. Other studies conducted in initial reception centres for asylum-seekers reported prevalence for suicidal ideation in the previous two weeks of $33.9 \%(n=510)$ in refugees from Afghanistan and Syria [17] in Sweden, and 5.6\% $(n=209)$ in Germany [18].

Based on the studies described above, it is safe to say there is a great deal of variation in the prevalence of suicidal ideation. Factors related to suicidal ideation in refugees are: inability to provide for family (e.g. work disability; 19), low levels of social support, anxiety, depression [5, 20], high mental distress [17], low quality of life [16], insecure visa status [19].

\section{Suicide attempts}


A study by Nock et al. [10] analyzed cross-national sample data (17 developed and developing countries) on suicide attempts; they found a lifetime prevalence of $2.7 \%$. The statistics in developing countries $(0.7 \%-4.7 \%)$ and developed countries $(0.5 \%-5.0 \%)$ are similar. The likelihood of those who experience suicidal ideation ever attempting suicide is estimated to be $29.0 \%$ [10].

Data from the World Mental Health Survey (WMH, conducted from 2001-2007, $n=108,705$ ) identified sociodemographic characteristics (age, sex, education, family income, marital status, and employment), parental psychopathology (major depressive episode, panic disorder, generalized anxiety disorder, substance use disorder, antisocial personality disorder), childhood adversities (childhood losses and family dysfunction, major physical illness), respondent's past suicidality and respondent's mental health status in the past 12 months as predictors of suicide attempts [11]. Sundvall et al. [21] compared asylum seekers and Swedish citizens (all people with a Swedish personal identity number) in terms of factors that influenced recent suicide attempts. Swedish citizens had different risk factors and disease patterns compared to asylum seekers, among whom suicide attempts appear to be driven by the asylum decision process, previous mental health problems, and pre-migration stressors. Suicide attempts have the highest predictive power in predicting future suicides [22] and therefore require special attention as a key risk factor.

There are several studies investigating suicide attempts in refugees. Incidence rates in refugee camps in Thailand range from 30-35 per 100,000 refugees in 2014-2016 [23]. In Sweden, three cohorts (1999-2009) of the entire Swedish population were studied (approximately 5 million in each cohort, 3.3-5.0\% refugees): hazard ratios regarding suicide attempt in refugees, compared to Swedish-born, range from 0.381.25 depending on country of birth. The results were either not significant or refugees showed a lower risk of suicide attempts [24]. 25 [25] report $0.8 \%(n=129)$ suicide attempts during the past year compared to $0.2 \%(n=1,290)$ in Korean nationals.

In his systematic review and meta-analysis, Amiri [26] reports on the prevalence of suicidal ideation ( $\left.16 \%, \mathrm{Cl}: 0.12-0.20, \mathrm{I}^{2}=99.4 \%\right)$ and suicide attempts (6\%, Cl: $\left.0.05-0.08, \mathrm{I}^{2}=98.0 \%\right)$. His analyses include prevalence data on refugees as well as other groups of immigrants. In our metaanalysis, we focus on refugee samples only. Because there is considerable evidence of significantly elevated prevalence rates of mental disorders among refugees compared with native-born and non-refugee immigrant populations (e.g. 25), it does not seem reasonable to compute overall prevalence among both refugees and other immigrant groups together. Therefore, this meta-analysis only includes studies in non-clinical populations and studies examining refugees (and asylum seekers) shortly after their arrival in host countries or refugee camps.

\section{Method}

\section{Search strategy and selection criteria}

Inclusion criteria as well as the methods of analysis were specified and documented at the beginning of the literature search. For this, we used the PICOS scheme ([P] patient population or disease to be treated, [I] interventions or exposures, [C] comparison group, [O] outcome or endpoint, and [S] study design chosen) to structure the literature search [27]. The criteria are shown in Table 1.

Table 1

Inclusion and exclusion criteria according to PICOS scheme (O'Connor et al., 2008)

\begin{tabular}{|c|c|}
\hline \multicolumn{2}{|c|}{ Inclusion criteria } \\
\hline Intervention & not required \\
\hline Comparison & not required \\
\hline Outcome & detection of suicidal ideation and attempts in refugees and asylum seekers \\
\hline Study type & empirical studies on the prevalence of suicidal ideation and suicide attempt \\
\hline $\begin{array}{l}\text { Study } \\
\text { design }\end{array}$ & $\begin{array}{l}\text { cross-sectional or longitudinal studies on the prevalence of suicidal ideation and suicide attempts; written in English or } \\
\text { German language; published until August } 2020\end{array}$ \\
\hline \multicolumn{2}{|c|}{ Exclusion criteria } \\
\hline \multicolumn{2}{|c|}{ - immigrants, living in the host country for a long time (first, second... generation immigrants) } \\
\hline - studies focu & d on refugees or asylum seekers under the age of 16 years \\
\hline - studies con & ted in clinical populations \\
\hline
\end{tabular}

\footnotetext{
***Please insert Table 1 about here***
}

We followed the PRISMA (Preferred Reporting Items for Systematic reviews and Meta-Analyses) guidelines for reporting systematic reviews and meta-analysis, which define all sections of a systematic review and meta-analysis from title to conclusion and provide guidance on the 
presentation of the process and the results [28].

All studies published up through August 2020 and written in English were considered for the analysis. We searched PubMed, Web of Science, PubPsych, and Psyclnfo for articles reporting on prevalence rates of suicidal ideation and suicide attempts. The following search terms were used: "suicidal ideation/ asylum seekers/ refugees", "suicide attempt/ asylum seekers/ refugees", and "suicidal behavior/ asylum seekers/ refugees", with and without the term "prevalence".

First, the articles were selected by title and abstract. Next, the full texts were screened. The screening of the abstracts was performed independently and simultaneously by a student assistant and a research assistant. The screening of the full articles was conducted exclusively by the the research assistant. In case of ambiguities, the senior author was consulted and a joint decision was made. Articles were chosen for inclusion in the meta-analysis based on the inclusion and exclusion criteria defined beforehand and the completeness of the data. If the same sample was reported on in several articles, we selected the article with the most comprehensive information. In some cases, we contacted the authors of the articles to get more information on their data.

\section{Assessment of methodological quality}

The factors of the quality assessment tool EPHPP (Effective Public Health Practice Project, 29) applicable to this analysis were used to assess the quality of the selected studies. For this purpose, the individual sections were classified as strong (1), moderate (2), and weak (3) in quality according to a predefined evaluation key [30]. The overview of this quality assessment can be found in Table 2.

Table 2

Quality Assessment of included studies (EPHPP)

\begin{tabular}{|c|c|c|c|c|c|c|c|}
\hline $\begin{array}{l}\text { Author and } \\
\text { year of } \\
\text { publication }\end{array}$ & Selection bias & Rating & Study design & Rating & Data collection method & Rating & $\begin{array}{l}\text { Rating } \\
\text { total }\end{array}$ \\
\hline $\begin{array}{l}\text { Akinyemi et al. } \\
(2015)\end{array}$ & random selection & moderate & $\begin{array}{l}\text { cross-sectional, } \\
\text { cluster } \\
\text { sampling }\end{array}$ & strong & $\begin{array}{l}\text { Mini-International } \\
\text { Neuropsychiatric Interview } \\
\text { (MINI), last month }\end{array}$ & strong & moderate \\
\hline Alley (1982) & random selection & moderate & $\begin{array}{l}\text { statewide } \\
\text { survey, cross- } \\
\text { sectional }\end{array}$ & moderate & - & weak & moderate \\
\hline $\begin{array}{l}\text { Bhui et al. } \\
\text { (2003) }\end{array}$ & random selection & strong & cross-sectional & strong & $\begin{array}{l}\text { Interview, Beck Depression } \\
\text { Inventory (BDI), last two } \\
\text { weeks }\end{array}$ & strong & strong \\
\hline $\begin{array}{l}\text { Cochran et al. } \\
\text { (2013) }\end{array}$ & random selection & moderate & cross-sectional & strong & $\begin{array}{l}\text { Interviews, lifetime and last } \\
\text { month }\end{array}$ & moderate & moderate \\
\hline $\begin{array}{l}\text { Falb et al. } \\
\text { (2013) }\end{array}$ & random selection & strong & $\begin{array}{l}\text { survey, } \\
\text { cross-sectional }\end{array}$ & strong & $\begin{array}{l}\text { Reproductive Health Toolkit } \\
\text { for Conflict-Affected } \\
\text { Women, last month }\end{array}$ & moderate & strong \\
\hline $\begin{array}{l}\text { Führer et al. } \\
(2016)\end{array}$ & random selection & moderate & $\begin{array}{l}\text { survey, } \\
\text { cross-sectional }\end{array}$ & strong & $\begin{array}{l}\text { Hopkins-Symptom- } \\
\text { Checklist-25 (HSCL-25), last } \\
\text { week }\end{array}$ & strong & strong \\
\hline $\begin{array}{l}\text { Leiler et al. } \\
\text { (2019) }\end{array}$ & random selection & moderate & $\begin{array}{l}\text { survey, } \\
\text { cross-sectional }\end{array}$ & strong & PHQ-9, last two weeks & strong & strong \\
\hline $\begin{array}{l}\text { Meyerhoff et } \\
\text { al. }(2020)\end{array}$ & random selection & moderate & cross-sectional & strong & $\begin{array}{l}\text { Beck Scale for Suicidal } \\
\text { ideation (BSS), last week }\end{array}$ & strong & moderate \\
\hline $\begin{array}{l}\text { Nickerson et } \\
\text { al. (2019) }\end{array}$ & random selection & moderate & $\begin{array}{l}\text { cross-sectional, } \\
\text { snowball- } \\
\text { sampling }\end{array}$ & strong & PHQ-9, last two weeks & strong & strong \\
\hline $\begin{array}{l}\text { Rahman et al. } \\
\text { (2003) }\end{array}$ & $\begin{array}{l}\text { random selection } \\
\text { in primary health } \\
\text { care }\end{array}$ & moderate & $\begin{array}{l}\text { survey, } \\
\text { cross-sectional }\end{array}$ & moderate & $\begin{array}{l}\text { Self-Reporting } \\
\text { Questionnaire (SRQ-20), } \\
\text { last month }\end{array}$ & moderate & moderate \\
\hline $\begin{array}{l}\text { Sohn et al. } \\
\text { (2019) }\end{array}$ & random selection & moderate & $\begin{array}{l}\text { survey, } \\
\text { cross-sectional }\end{array}$ & moderate & Interview, last year & moderate & moderate \\
\hline
\end{tabular}

\footnotetext{
***Please insert Table 2 about here ${ }^{\star \star *}$
} 
A data extraction form was used to extract equivalent information from the articles. This included sample size and gender distribution, prevalence of suicidal ideation, and prevalence of suicide attempts (separately, when possible, for women, men, and gender-diverse).

The analyses were performed with RStudio [31], using the packages "meta"[32] and "metafor"[33] (see also 34). There are transformation methods that can be used to avoid inappropriate weighting of studies with small or large prevalence. In the present case, data was transformed with an arcsine algorithm to stabilize sampling variances [35]. The data were then back-transformed to see the output for the true summary proportion and its $95 \%$ confidence interval. A random effects model was selected for pooling the data using the restricted DerSimonian-Lairs estimator. We chose a random effects model because we expected variation across studies (heterogeneity), for example, in the methods used and their samples. To test for heterogeneity, we used $\mathrm{I}^{2}$ to quantify it, and Cochrane's Q to assess statistical significance. We also used forest plots to check for asymmetry. Outlier analyses were also carried out. The adjustment for outliers is only useful if it reduces heterogeneity and/or if there is a theoretical reason (e.g. population, method) why studies can be identified as outliers [34, 36]. Neither of these aspects were met in the present meta-analysis, hence we did not adjust for outliers.

Funnel plots were performed to explore the publication bias. Moreover rank correlation test [37] and Egger's regression test [38] were used to assess publication bias.

\section{Results}

The search of the digital platforms resulted in 294 hits that were screened and systematically examined for the defined criteria. An overview of this process can be found in Fig. 1.

After excluding all studies that did not match inclusion criteria, did match the exclusion criteria, or were duplicates, 11 studies could be included in the meta-analysis. Detailed information on these is presented in Table 3. There was a wide range in sample size and quality of data collection. The same was true of the assessment methods, which included interviews, self-report questionnaires, and individual items of questionnaires or surveys. The periods of time for which suicidal ideation was examined ranged from one week $(n=2)$, two weeks $(n=4)$ and four weeks $(n=2)$. For men, the distribution was as follows: one week $(n=1)$, two weeks $(n=1)$, and four weeks ( $n=1)$; and for women, one week $(n=1)$, two weeks $(n=1)$, and four weeks $(n=3)$. The periods of time for suicide attempts ranged from one week $(n=1)$, two weeks $(n=$ $1)$, and four weeks $(n=1)$ to one year $(n=1)$ (in one article there was no indication of the survey period). 
Table 3

Study characteristics

\begin{tabular}{|c|c|c|c|c|c|c|c|c|c|}
\hline $\begin{array}{l}\text { Author and } \\
\text { year of } \\
\text { publication }\end{array}$ & $\begin{array}{l}\text { Suicidal } \\
\text { ideation }\end{array}$ & $\begin{array}{l}\text { Suicide } \\
\text { attempt }\end{array}$ & $\begin{array}{l}\text { Sample } \\
\text { size }\end{array}$ & \multicolumn{2}{|c|}{$\begin{array}{l}\text { Gender } \\
\text { distribution }\end{array}$} & $\begin{array}{l}\text { Age } \\
\text { distribution }\end{array}$ & Population & \multicolumn{2}{|c|}{ Country } \\
\hline $\begin{array}{l}\text { Akinyemi } \\
\text { et al. } \\
(2015)\end{array}$ & $\begin{array}{l}121 \\
(27.3 \%) \\
\text { female: } \\
66 \\
\text { male: } 55\end{array}$ & - & 444 & \multicolumn{2}{|c|}{$\begin{array}{l}\text { female: } 263 \\
\text { male: } 181\end{array}$} & $\begin{array}{l}18 \text { and } \\
\text { older } \\
\text { mean: } 34.7 \\
(S D=12.8)\end{array}$ & $\begin{array}{l}\text { refugees } \\
\text { (Liberians, Sierra } \\
\text { Leonans, } \\
\text { Sudanese, } \\
\text { Congolese, } \\
\text { Eritreans) }\end{array}$ & \multicolumn{2}{|c|}{$\begin{array}{l}\text { Oru-ljebu, South-West } \\
\text { Nigeria }\end{array}$} \\
\hline $\begin{array}{l}\text { Alley } \\
\text { (1982) }\end{array}$ & - & $\begin{array}{l}6 \\
(0.14 \%) \\
\text { female: } \\
4 \\
\text { male: } 2\end{array}$ & 4.192 & \multicolumn{2}{|l|}{-} & $17-52$ & $\begin{array}{l}\text { Indochinese } \\
\text { refugees }\end{array}$ & \multicolumn{2}{|c|}{ Utha, USA } \\
\hline $\begin{array}{l}\text { Bhui et al. } \\
\text { (2003) }\end{array}$ & $\begin{array}{l}62 \\
(34.4 \%) \\
\text { female: } \\
24 \\
\text { male: } 38\end{array}$ & - & 180 & \multicolumn{2}{|c|}{$\begin{array}{l}\text { female: } 89 \\
\text { male: } 91\end{array}$} & $\begin{array}{l}\text { mean: } 40.4 \\
\text { range: } 20- \\
88\end{array}$ & Somali refugees & \multicolumn{2}{|c|}{ Greenwich/London, GB } \\
\hline $\begin{array}{l}\text { Cochran et } \\
\text { al. (2013) }\end{array}$ & $\begin{array}{l}13 \\
\text { (lifetime) } \\
(3.07 \%) \\
9 \text { (last } \\
\text { month) } \\
(2.13 \%)\end{array}$ & $\begin{array}{l}1 \\
(0.24 \%)\end{array}$ & 423 & \multicolumn{2}{|c|}{$\begin{array}{l}\text { female: } 202 \\
\text { male: } 221\end{array}$} & $\begin{array}{l}18 \text { and } \\
\text { older }\end{array}$ & Buhatan refugees & \multicolumn{2}{|c|}{$\begin{array}{l}\text { Arizona Georgia, New York } \\
\text { and Texas, USA }\end{array}$} \\
\hline $\begin{array}{l}\text { Falb et al. } \\
\text { (2013) }\end{array}$ & $\begin{array}{l}\text { female: } \\
63 \\
(7.43 \%)\end{array}$ & - & $\begin{array}{l}\text { female: } \\
848\end{array}$ & \multicolumn{2}{|c|}{ only women } & $\begin{array}{l}15-49 \\
\text { mean: } \\
32.12(\mathrm{SD} \\
=8.42)\end{array}$ & $\begin{array}{l}\text { female refugees } \\
\text { in a partnership }\end{array}$ & \multicolumn{2}{|c|}{$\begin{array}{l}\text { Thai-Burma border, } \\
\text { Myanmar \& Thailand }\end{array}$} \\
\hline $\begin{array}{l}\text { Führer et } \\
\text { al. (2016) }\end{array}$ & $\begin{array}{l}33 \\
(15.79 \%)^{*} \\
\text { female: } 6 \\
\text { male: } 25 \\
\text { others: } 1 \\
\text { missing:1 }\end{array}$ & - & 209 & \multicolumn{2}{|c|}{$\begin{array}{l}\text { female: } 24 \\
\text { male: } 177 \\
\text { others: } 3 \\
\text { missing:5 }\end{array}$} & $\begin{array}{l}16 \text { and } \\
\text { older }\end{array}$ & asylum-seekers & \multicolumn{2}{|c|}{ Halle, Germany } \\
\hline $\begin{array}{l}\text { Leiler et al. } \\
\text { (2019) }\end{array}$ & $\begin{array}{l}173 \\
(33.92 \%)\end{array}$ & - & 510 & & $\begin{array}{l}\text { female: } 136 \\
\text { male: } 367 \\
\text { others: } 7\end{array}$ & $\begin{array}{l}18 \text { and } \\
\text { older }\end{array}$ & $\begin{array}{l}\text { refugees } \\
\text { (Afghanistan }\end{array}$ & Syria) & $\begin{array}{l}\text { Jämtland- } \\
\text { Härjedalen county, } \\
\text { Sweden }\end{array}$ \\
\hline \multicolumn{10}{|c|}{$\begin{array}{l}\text { *After correspondence with the authors, we received the detailed frequency tables on suicidal ideation and classified those who } \\
\text { responded with } 1 \text { ('a little"), } 2 \text { ('quite a bit') to } 3 \text { ('extremly') as individuals with suicidal ideation. The classification thus differs from that in } \\
\text { the paper. }\end{array}$} \\
\hline \multicolumn{10}{|c|}{ Table 3 Continued } \\
\hline $\begin{array}{l}\text { Meyerhoff } \\
\text { et al. } \\
\text { (2020) }\end{array}$ & $4(6.67 \%)$ & $4(7.55 \%)$ & 60 (ide & & $\begin{array}{l}\text { ideation: } \\
\text { female: } 29 \\
\text { male: } 31 \\
\text { attempt: } \\
\text { female: } 22 \\
\text { male: } 31\end{array}$ & $\begin{array}{l}\text { 18-65 } \\
\text { mean } \\
\text { women } \\
43.7 \text { (SI } \\
\text { 10.5) } \\
\text { mean n } \\
38.2 \\
(\mathrm{SD}=1(\end{array}$ & $\begin{array}{l}= \\
\text { en: } \\
\text {.8) }\end{array}$ & ees & $\begin{array}{l}\text { greater Burlington, } \\
\text { Vermont region, } \\
\text { USA }\end{array}$ \\
\hline
\end{tabular}




\begin{tabular}{|c|c|c|c|c|c|c|c|}
\hline $\begin{array}{l}\text { Author and } \\
\text { year of }\end{array}$ & $\begin{array}{l}\text { Suicidal } \\
\text { ideation }\end{array}$ & $\begin{array}{l}\text { Suicide } \\
\text { attempt }\end{array}$ & $\begin{array}{l}\text { Sample } \\
\text { size }\end{array}$ & $\begin{array}{l}\text { Gender } \\
\text { distribution }\end{array}$ & $\begin{array}{l}\text { Age } \\
\text { distribution }\end{array}$ & ulation & \\
\hline \multirow{4}{*}{$\begin{array}{l}\text { Nickerson } \\
\text { et al. } \\
\text { (2019) }\end{array}$} & $\begin{array}{l}102 \\
(39.38 \%)\end{array}$ & - & 259 & female: 81 & \multirow{4}{*}{$\begin{array}{l}18 \text { and } \\
\text { older, } \\
\text { mean: } \\
38.11 \text { (SD } \\
=11.8)\end{array}$} & $\begin{array}{l}\text { refugees or asylum- } \\
\text { seekers (Iraq, Syria, }\end{array}$ & \multirow[t]{4}{*}{ Australia } \\
\hline & & & & male: 178 & & $\begin{array}{l}\text { Iran, Sri Lanka, } \\
\text { Afghanistan) with } \\
\text { no secure visa }\end{array}$ & \\
\hline & \multirow{2}{*}{$\begin{array}{l}154 \\
(18.64 \%)\end{array}$} & \multirow[t]{2}{*}{-} & \multirow[t]{2}{*}{826} & female: 384 & & \multirow{2}{*}{$\begin{array}{l}\text { refugees or asylum- } \\
\text { seekers (Iraq, Syria, } \\
\text { Iran, Sri Lanka, } \\
\text { Afghanistan) with } \\
\text { secure visa }\end{array}$} & \\
\hline & & & & male: 442 & & & \\
\hline \multirow{2}{*}{$\begin{array}{l}\text { Rahman et } \\
\text { al. (2003) }\end{array}$} & \multirow{2}{*}{$\begin{array}{l}\text { female: } \\
96 \\
(32.32 \%)\end{array}$} & \multirow[t]{2}{*}{-} & \multirow[t]{2}{*}{ female: 297} & \multirow[t]{2}{*}{ only women } & mean: 28.2 & \multirow{2}{*}{$\begin{array}{l}\text { female refugees } \\
\text { which are mothers }\end{array}$} & \multirow{2}{*}{$\begin{array}{l}\text { Shamshatu and } \\
\text { Shalman; } \\
\text { Afghanistan }\end{array}$} \\
\hline & & & & & $(S D=7.3)$ & & \\
\hline \multirow{4}{*}{$\begin{array}{l}\text { Sohn et al. } \\
\text { (2019) }\end{array}$} & \multirow[t]{4}{*}{ - } & \multirow[t]{4}{*}{1 (0.78\%) } & \multirow[t]{4}{*}{129} & female: 93 & $<31: 44$ & \multirow{4}{*}{$\begin{array}{l}\text { refugees and } \\
\text { asylum seekers } \\
\text { (Nigeria, Ethiopia, } \\
\text { Liberia, Yemen, } \\
\text { Egypt) }\end{array}$} & \multirow{4}{*}{$\begin{array}{l}\text { Seoul and } \\
\text { Gyeonggi province, } \\
\text { Korea }\end{array}$} \\
\hline & & & & \multirow[t]{3}{*}{ male: 36} & $31-40: 50$ & & \\
\hline & & & & & $41-50: 27$ & & \\
\hline & & & & & $>51: 8$ & & \\
\hline
\end{tabular}

Figure 2 gives an overview of the prevalence of suicidal ideation across the studies. For suicidal ideation, the studies ranged from $2.13 \%$ $34.4 \%$, and for suicide attempts from $0.14-7.55 \%$.

The overall prevalence of suicidal ideation was $20.5 \%(\mathrm{Cl}: 0.11-0.32, n=8)$. Heterogeneity was explored statistically using $\mathrm{I}^{2}=98 \%$ and Cochrane's $Q=308.61, p<.0001$. Forest plots were used to graphically test heterogeneity (Fig. 2). There was significant heterogeneity between studies. For this reason, subgroup analyses would have been useful, but could not be performed due to the small number of studies.

For suicidal ideation in women, an overall prevalence of $22.3 \%(\mathrm{Cl}: 0.10-0.38, n=5)$ was calculated, but high heterogeneity exists in this subpopulation $\left(I^{2}=97 \%, Q=127.80, p<.0001\right)$ (see Fig. 3). The overall prevalence of suicidal ideation among men was $23.3 \%$ (Cl: $0.13-0.35, n$ $=3$ ) with high significant heterogeneity $\left(I^{2}=87 \%, Q=14.98, p<.0006\right)$ (see Fig. 4). The slightly higher prevalence compared to the total population is due to the fact that not all of the 11 studies offered data separated by gender. Two factors were at work here: 1) fewer studies could be used to calculate the gender-specific prevalence; and 2) two of the studies included only examined women [39, 40].

Suicide attempts had an overall prevalence of $0.57 \%(\mathrm{Cl}: 0.00-0.02, n=4)$. Heterogeneity was significantly high $\left(I^{2}=81 \%, Q=15.88, p<.0012\right)$ (see Fig. 5).

Publication bias can likely be ruled out, as the Begg and Mazumdar [37] rank correlation test result, $p=.0833$, was not significant. In parallel, Eggers regression test [38], $\mathrm{p}=.0020$, was significant, but the explanatory power is only moderate in samples comprised of fewer than 25 studies. In addition, a funnel plot was created to test for publication bias (see Appendix; figure A1), indicating funnel plot asymmetry and high heterogeneity. Because prevalence data do not describe positive or negative effects (e.g. effectiveness of an intervention), low prevalence rates are no less likely to be published than high ones. Therefore, classical methods for assessing publication bias in meta-analyses of observational studies might be of limited use [34].

\section{Discussion}

The meta-analysis presented here calculated overall prevalence of suicidal ideation and attempts in refugees and asylum seekers. Based on the eight studies included, a prevalence of $20.5 \%$ (range: $2.13 \%-34.4 \%$ ) was found for suicidal ideation across both genders. When distinguished by gender, a prevalence of $22.3 \%(n=5)$ was found for women and $23.3 \%(n=3)$ for men. Because not all studies reported prevalence for suicidal ideation stratified by sex, fewer studies could be included in the gender-differentiated analysis. In regard to the prevalence in women, it should be further mentioned that some studies were included in which only women were examined [39, 40]. In determining an overall prevalence of suicide attempts, it was possible to include four studies, yielding a prevalence of $0.57 \%$ (range: $0.14 \%$ $7.55 \%)$.

Compared to global prevalence data [10-12], there is a higher prevalence of suicidal ideation among refugees. Making direct comparisons is difficult, however, because global prevalence data are often recorded as lifetime or 12-month prevalence rates. That said, in the studies 
considered here, periodic prevalence rates were reported that included the $1-4$ weeks previous to when the surveys were administered (see Table 2). Only Cochran et al. [41] reported a lifetime prevalence of suicidal ideation among Bhutanese refugees in the United States of $3 \%$ ( $\mathrm{n}=$ 423). This corresponds to the lower range of previously reported global prevalence rates [10].

In looking at prevalence rates for suicide attempts, we found numbers similar to those reported in cross-national studies [10]. Again, comparison is difficult because the data on suicide attempts in the included studies reflects a variety of time periods ranging from one week to one year (see Table 2).

With one exception [18], studies on refugee populations report substantially higher prevalence rates of suicidal ideation compared to studies examining non-refugee populations or the general population. All in all, the results emphasize previous findings of increased psychological distress among refugees being associated with higher rates of suicidal ideation and suicide attempts. Amiri [26] determined the prevalence of suicidal ideation to be $16 \%$ (17\% in women, $10 \%$ in men) and suicide attempts $6 \%$ ( $7 \%$ in women, $1 \%$ in men) when he included studies done with various immigrant groups and refugees without distinguishing between them $(n=29)$.

As mentioned above, people who leave their country of origin do so for a variety of reasons; for refugees, the flight is more often accompanied by numerous traumatic events. In addition, it must be taken into account that immigrants who have already lived and worked in their new host country for several years are exposed to different stressors than people who have been on the run for the past few months or years, and have just arrived in a host country and/or have an uncertain asylum status (pre-, peri- and post-migration factors). On the other hand, there may be an increased vulnerability as a result of pre- and peri-migration stressors, which can result in mental disorders and suicidal ideation.

Studies in immigrant populations in different European countries (e.g. Germany, Sweden) show 1st generation immigrants having less suicidal ideation than host country residents or 2 nd generation immigrants (e.g. 42, 43). This phenomenon can be explained by the Protective Culture Model (e.g. 44 ). This model assumes that some protective factors against suicide might be linked with culture of origin, such as religious beliefs, stable family bonds, and social support. This reduces the stress of acculturation. However, this protection decreases with time spent in the host country, resulting in increased suicidal ideation and attempts in the second generation. In addition, the Resilient Immigrant Model (e.g. 45) also known as Healthy Migrant Effect assumes a selective effect during immigration processes, i.e., people with good health and high resilience are particularly able to cope with the challenges of migration. In the second generation, this selectivity would no longer exist. This could explain the good health of immigrants on average. Factors influencing suicidality among immigrants are acculturation stress, experiences of discrimination, cultural differences, and environmental factors, among others (for an overview, see 46). Also worth considering are post-migration stressors such as socioeconomic factors, social and interpersonal circumstances, and stressors related to the asylum process and immigration policies [16, 47], which can be burdensome. Taking into account these differences between refugees and/or asylum seekers compared to immigrants (immigrants or former refugees living in their host country for some time), it is not reasonable to equate their prevalence rates of suicidal ideation and attempts. The danger of doing so is that it could result in underestimating the general risk of suicidal ideation and suicide attempts among refugees and asylum seekers.

\section{Strengths and limitations}

The strengths of this analysis lie in the methodology that was used, which is based on current research standards [27, 32, 35, 48]. All studies were rated "moderate" or "strong" in quality assessment (Table 2). In some cases, however, the sample sizes were relatively small (e.g. 18,25 , $49,50)$, which could have an impact on external validity. Another limitation is the small number $(n=11)$ of studies that could be integrated into the meta-analysis after reviewing articles' full texts. For this reason, the generalizability of the results is of a rather limited nature. We included studies that were not initially designed as epidemiological studies, but in which descriptive data of the periodic prevalence of suicidal ideation and attempts among refugees and asylum seekers were recorded. Furthermore, no gray literature search was conducted, so there may be unpublished research that was not included. The generalizability of the results regarding suicidal ideation in women may be further impaired by the fact that very specific groups of women were studied, for example, female refugees in a partnership [39] or exclusively mothers [40], groups that may be affected by additional protective or risk factors not accounted for in the scope of the examinations.

In view of the different survey methods (mainly self-report) used to record suicidal ideation and suicide attempts, of the included studies, the appropriateness of calculating pooled prevalence estimates could be questioned as well as internal validity. In general, in order to compare test results in different cultural groups, equivalence in language and construct validity must be taken into account.

Because of high heterogeneity between studies, the pooled prevalence estimates should be interpreted with caution. Heterogeneity can be defined as any type of variability between studies in a systematic review or meta-analysis. Therefore possible covariates of heterogeneity can be the quality of the studies, the sample, the year of publication, and/or the research method used [51-53]. In order to be able to understand the variance across studies depending on the factors just mentioned, subgroup analyses are helpful. These, however, could not be performed in the present meta-analysis due to the small number of studies included (there must be at least 10 studies to perform a subgroup analysis, 
54). Thus, future research in the same field of interest should focus in more detail on subgroups regarding differences in host countries, cultural characteristics such as religion or attitudes toward mental disorders, country of origin, and flight duration and/or route, etc.

\section{Conclusions}

Understanding factors that influence suicidal ideation and predict suicide attempts is complex. Large non-biased epidemiological studies are needed to determine robust prevalence estimates. In addition, longitudinal studies are useful for tracking the persistence of suicidal ideation and repeated suicide attempts in refugees and asylum seekers.

Problems with the systematic recording of suicidal ideation and attempts in camps or initial accommodation facilities, for example, could be language barriers, stress due to low staffing ratios, and too few (specialized) staff for the assessment and treatment of somatic as well as mental illnesses. On the refugee side, shame and taboos around certain topics can be a challenge in reporting suicidal ideation and attempts.

Based on the results, it could be useful to screen newly arriving refugees for suicidal ideation and attempts and mental disorders in the initial accommodation facilities when they seek counseling or medical care. In this way, timely and appropriate help could be provided.

It should be noted that few studies systematically and adequately inquire about suicidal ideation and attempts. Since it is known that refugees and asylum seekers are exposed to immense stress and mental disorders such as depression, anxiety, and PTSD, it is essential to assess suicidal ideation and attempts in a person's past. In the context of studies dealing with the screening and monitoring of suicidality, the question has repeatedly been raised of whether directly asking about suicidal ideation and attempts might have iatrogenic effects for the respondents, i.e., whether it leads to an increase in suicidal ideation and attempts. Two randomized-controlled studies have examined this question and failed to find evidence to support this assumption $[55,56]$. Repeated measurements similarly failed to find a corresponding effect [57].

Interviewers may fear that the assessment might burden patients due to its intrusive nature or potentially destabilizing effect. This reservation should not however indeed keep them from asking about suicidal ideation and attempts. Inquiring about suicidal ideation or intentions does not increase respondents' vulnerability to them. On the contrary, when caregivers (social worker, psychologist, clinician, etc.) ask about suicidal ideation it can build trust with their client, promote reporting, and be a useful intervention in and of itself [58].

When screening, culturally sensitive as well as standardized diagnostic procedures that take psychometric properties (ensuring psychometrically validated language versions and cultural equivalence of language versions) into account should be used to detect suicidal ideation and attempts. Cultural identity, culturally-bound concepts of suffering, psychosocial stressors, and cultural characteristics of vulnerability and resilience, as well as cultural characteristics in the relationship between the person affected and those treating them are important for culturally sensitive diagnostics [59]. Respecting these factors is key to ensuring a sensitive approach to the respondents and the comparability of future studies. Furthermore, it should be possible to refer to diagnostic procedures that include people with a lower level of education, especially those who cannot read.

There are initial study results that indicate that in diagnostic interviews conducted with refugees (mainly people speaking Arabic), suicidal intentions should be mentioned indirectly to begin with. Later in the interview, however, the topic can and should be addressed directly [60]. This is an approach that is reported to increase the likelihood of receiving an honest and open response.

Although there is still no reliable model for predicting suicidal ideation, attempts, and suicides, improved recognition and understanding of clinical, psychological, cultural, and sociological factors may be helpful in identifying individuals at high risk and in helping to provide initial help or treatment (e.g. counseling, psychotherapy, acute psychiatry). There is preliminary research in refugee populations that addresses the specific risk factors for suicidal ideation (e.g. 5, 17, 19-21, 24). It would be of great interest to further examine the factors influencing suicidal ideation and attempts specifically in the refugee population to identify general risk factors. As part of this, the information could be used to develop and expand interventions to address suicidal behavior in refugees.

\section{Abbreviations}

- PICOS scheme ([P] patient population or disease to be treated, [l] interventions or exposures, [C] comparison group, [0] outcome or endpoint, and [S] study design chosen)

- PRISMA (Preferred Reporting Items for Systematic reviews and Meta-Analyses)

- EPHPP (Effective Public Health Practice Project)

\section{Declarations}


Consent for publication: Not Applicable

Availability of data and material: All data generated or analysed during this study are included in this published article [and its supplementary information files].

Competing interests: The authors declare that they have no competing interests.

Funding: No funding was obtained for this study.

Authors' contributions. E.H. undertook conception and design of the paper as well as obtaining, analyzing and interpreting the data, writing, preparing all figures and tables and revising the content of the paper. A.S. contributed to analyzing of data and revising the content of the paper. Y.N. and H.G. were both involved in conception and design of the paper as well as writing and revising the content of the paper. All authors interpreted the results and contributed to the final draft.

Acknowledgements: Not Applicable

\section{References}

1. La santé Omd, Saxena S, Krug EG, Chestnov O, editors. Preventing suicide: A global imperative. Geneva, Switzerland: World Health Organization; 2014.

2. Turecki G, Brent DA. Suicide and suicidal behaviour. The Lancet. 2016;387:1227-39. doi:10.1016/S0140-6736(15)00234-2.

3. Vijayakumar L. Suicide Among Refugees-A Mockery of Humanity. Crisis. 2016;37:1-4. doi:10.1027/0227-5910/a000385.

4. Ingabire CM, Richters A. Suicidal Ideation and Behavior Among Congolese Refugees in Rwanda: Contributing Factors, Consequences, and Support Mechanisms in the Context of Culture. Front Psychiatry. 2020;11:299. doi:10.3389/fpsyt.2020.00299.

5. Ao T, Shetty S, Sivilli T, Blanton C, Ellis H, Geltman PL, et al. Suicidal ideation and mental health of Bhutanese refugees in the United States. Journal of immigrant and minority health. 2016;18:828-35.

6. Tinghög P, Malm A, Arwidson C, Sigvardsdotter E, Lundin A, Saboonchi F. Prevalence of mental ill health, traumas and postmigration stress among refugees from Syria resettled in Sweden after 2011: a population-based survey. BMJ Open. 2017;7:e018899. doi:10.1136/bmjopen-2017-018899.

7. Giacco D, Laxhman N, Priebe S. Prevalence of and risk factors for mental disorders in refugees. Seminars in Cell \& Developmental Biology. 2018;77:144-52. doi:10.1016/j.semcdb.2017.11.030.

8. Priebe S, Giacco D, El-Nagib R. Public health aspects of mental health among migrants and refugees: a review of the evidence on mental health care for refugees, asylum seekers and irregular migrants in the WHO European Region: World Health Organization. Regional Office for Europe; 2016.

9. Nesterko Y, Jäckle D, Friedrich M, Holzapfel L, Glaesmer H. Prevalence of post-traumatic stress disorder, depression and somatisation in recently arrived refugees in Germany: an epidemiological study. Epidemiol Psychiatr Sci. 2020;29.

10. Nock MK, Borges G, Bromet EJ, Alonso J, Angermeyer M, Beautrais A, et al. Cross-national prevalence and risk factors for suicidal ideation, plans and attempts. Br J Psychiatry. 2008;192:98-105. doi:10.1192/bjp.bp.107.040113.

11. Borges G, Nock MK, Haro Abad JM, Hwang I, Sampson NA, Alonso J, et al. Twelve-month prevalence of and risk factors for suicide attempts in the World Health Organization World Mental Health Surveys. J Clin Psychiatry. 2010;71:1617-28. doi:10.4088/JCP.08m04967blu.

12. Liu RT, Bettis AH, Burke TA. Characterizing the phenomenology of passive suicidal ideation: a systematic review and meta-analysis of its prevalence, psychiatric comorbidity, correlates, and comparisons with active suicidal ideation. Psychol Med. 2020;50:367-83. doi:10.1017/S003329171900391X.

13. Franklin JC, Ribeiro JD, Fox KR, Bentley KH, Kleiman EM, Huang X, et al. Risk factors for suicidal thoughts and behaviors: A meta-analysis of 50 years of research. Psychological Bulletin. 2017;143:187-232. doi:10.1037/bul0000084.

14. Calati R, Laglaoui Bakhiyi C, Artero S, Ilgen M, Courtet P. The impact of physical pain on suicidal thoughts and behaviors: Meta-analyses. J Psychiatr Res. 2015;71:16-32. doi:10.1016/j.jpsychires.2015.09.004.

15. Bentley KH, Franklin JC, Ribeiro JD, Kleiman EM, Fox KR, Nock MK. Anxiety and its disorders as risk factors for suicidal thoughts and behaviors: A meta-analytic review. Clinical Psychology Review. 2016;43:30-46. doi:10.1016/j.cpr.2015.11.008.

16. Akinyemi 00, Atilola O, Soyannwo T. Suicidal ideation: Are refugees more at risk compared to host population? Findings from a preliminary assessment in a refugee community in Nigeria. Asian J Psychiatr. 2015;18:81-5. doi:10.1016/j.ajp.2015.09.001.

Page $10 / 14$ 
17. Leiler A, Hollifield M, Wasteson E, Bjärtå A. Suicidal ideation and severity of distress among refugees residing in asylum accommodations in Sweden. International journal of environmental research and public health. 2019;16:2751.

18. Führer A, Eichner F, Stang A. Morbidity of asylum seekers in a medium-sized German city. Eur J Epidemiol. 2016;31:703-6. doi:10.1007/s10654-016-0148-4.

19. Nickerson A, Byrow Y, O'Donnell M, Mau V, McMahon T, Pajak R, et al. The association between visa insecurity and mental health, disability and social engagement in refugees living in Australia. Eur J Psychotraumatol. 2019;10:1688129. doi:10.1080/20008198.2019.1688129.

20. Björkenstam E, Helgesson M, Amin R, Lange T, Mittendorfer-Rutz E. Mental disorders and suicidal behavior in refugees and Swedish-born individuals: is the association affected by work disability? Soc Psychiatry Psychiatr Epidemiol 2020. doi:10.1007/s00127-019-01824-5.

21. Sundvall M, Tidemalm DH, Titelman DE, Runeson B, Bäärnhielm S. Assessment and treatment of asylum seekers after a suicide attempt: a comparative study of people registered at mental health services in a Swedish location. BMC Psychiatry. 2015;15:235.

22. World Health Organization. Suicide: Fact sheet. 20172017.

23. International Organization for Migration. Assessment of Suicide Risks and Factors in a Refugee Camp in Thailan. 2017. https://progressivevoicemyanmar.org/wp-content/uploads/2017/06/IOM-Mission-in-Thailand-Assessment-of-Suicide-Risks-and-Factorsin-a-Refugee-Camp-in-Thailand.pdf. Accessed 21 Jan 2021.

24. Amin R, Helgesson M, Runeson B, Tinghög P, Mehlum L, Qin P, et al. Suicide attempt and suicide in refugees in Sweden - a nationwide population-based cohort study. Psychol Med. 2019:1-10. doi:10.1017/S0033291719003167.

25. Sohn JH, Lim J, Lee JS, Kim K, Lim S, Byeon N, et al. Prevalence of possible depression and post-traumatic stress disorder among community dwelling adult refugees and refugee applicants in South Korea. Journal of Korean medical science. $2019 ; 34$.

26. Amiri S. Prevalence of Suicide in Immigrants/Refugees: A Systematic Review and Meta-Analysis. Arch Suicide Res. 2020:1-36. doi:10.1080/13811118.2020.1802379.

27. Liberati A, Altman DG, Tetzlaff J, Mulrow C, Gøtzsche PC, loannidis JPA, et al. The PRISMA statement for reporting systematic reviews and meta-analyses of studies that evaluate healthcare interventions: explanation and elaboration. BMJ. 2009;339:b2700. doi:10.1136/bmj.b2700.

28. Moher D, Liberati A, Tetzlaff J, Altman DG, Prisma Group. Preferred reporting items for systematic reviews and meta-analyses: the PRISMA statement. PLoS med. 2009;6:e1000097.

29. Armijo-Olivo S, Stiles CR, Cummings GG. Assessment of study quality for systematic reviews: A comparison of the Cochrane Collaboration Risk of Bias Tool and the. 1365-2753. 2010.

30. McMaster University. Effective Public Health Practice Quality Assessment Tool for Quantitative Studies. McMaster University School of Nursing. 2008.

31. Team R. RStudio: integrated development for R. RStudio, Inc., Boston, MA URL http://www. rstudio. com. 2015;42:14.

32. Balduzzi S, Rücker G, Schwarzer G. How to perform a meta-analysis with R: a practical tutorial. Evidence-based mental health. 2019;22:153-60.

33. Viechtbauer W. Conducting meta-analyses in R with the metafor package. Journal of statistical software. 2010;36:1-48.

34. Wang N. Conducting meta-analyses of proportions in R. Research Gate: College Station, TX, USA. 2017.

35. Barendregt JJ, Doi SA, Lee YY, Norman RE, Vos T. Meta-analysis of prevalence. J Epidemiol Community Health. 2013;67:974-8.

36. Devillé WL, Buntinx F, Bouter LM, Montori VM, Vet HCW de, van der Windt DAWM, Bezemer PD. Conducting systematic reviews of diagnostic studies: didactic guidelines. BMC Med Res Methodol. 2002;2:9. doi:10.1186/1471-2288-2-9.

37. Begg CB, Mazumdar M. Operating characteristics of a rank correlation test for publication bias. Biometrics. 1994:1088-101.

38. Egger M, Smith GD, Schneider M, Minder C. Bias in meta-analysis detected by a simple, graphical test. Bmj. 1997;315:629-34.

39. Falb KL, McCormick MC, Hemenway D, Anfinson K, Silverman JG. Suicide ideation and victimization among refugee women along the Thai-Burma border. J Trauma Stress. 2013;26:631-5. doi:10.1002/jts.21846.

40. Rahman A, Hafeez A. Suicidal feelings run high among mothers in refugee camps: a cross-sectional survey. Acta Psychiatr Scand. 2003;108:392-3. doi:10.1034/j.1600-0447.2003.00220.x.

41. Cochran J, Geltman PL, Ellis H, Brown C, Anderton S, Montour J, et al. Suicide and suicidal ideation among Bhutanese refugees-United States, 2009-2012. MMWR Morb Mortal Wkly Rep. 2013;62:533.

42. Beutel ME, Jünger $C$, Klein EM, Wild P, Lackner KJ, Blettner M, et al. Depression, anxiety and suicidal ideation among 1 (st) and 2(nd) generation migrants - results from the Gutenberg health study. BMC Psychiatry. 2016;16:288. doi:10.1186/s12888-016-0995-2.

43. Di Thiene D, Alexanderson K, Tinghög P, La Torre G, Mittendorfer-Rutz E. Suicide among first-generation and second-generation immigrants in Sweden: association with labour market marginalisation and morbidity. J Epidemiol Community Health. 2015;69:467-73.

Page $11 / 14$ 
doi:10.1136/jech-2014-204648.

44. Peña JB, Wyman PA, Brown CH, Matthieu MM, Olivares TE, Hartel D, Zayas LH. Immigration generation status and its association with suicide attempts, substance use, and depressive symptoms among Latino adolescents in the USA. Prevention science. 2008;9:299-310.

45. Hjern A, Allebeck P. Suicide in first-and second-generation immigrants in Sweden A comparative study. Soc Psychiatry Psychiatr Epidemiol. 2002;37:423-9.

46. Ratkowska KA, Leo D de. Suicide in immigrants: An overview. 2013.

47. Li SSY, Liddell BJ, Nickerson A. The relationship between post-migration stress and psychological disorders in refugees and asylum seekers. Curr Psychiatry Rep. 2016;18:1-9.

48. Pigott TD, Polanin JR. Methodological Guidance Paper: High-Quality Meta-Analysis in a Systematic Review. Review of Educational Research. 2019;90:24-46. doi:10.3102/0034654319877153.

49. Bhui K, Abdi A, Abdi M, Pereira S, Dualeh M, Robertson D, et al. Traumatic events, migration characteristics and psychiatric symptoms among Somali refugees. Soc Psychiatry Psychiatr Epidemiol. 2003;38:35-43.

50. Meyerhoff J, Rohan KJ. The desire to be dead among Bhutanese refugees resettled in the United States: Assessing risk. American Journal of Orthopsychiatry. 2020;90:236-45. doi:10.1037/ort0000429.

51. Thomas J. Cochrane handbook for systematic reviews of interventions. Chichester West Sussex, Hoboken NJ: John Wiley \& Sons; 2019.

52. Higgins JPT, Green S, editors. Cochrane handbook for systematic reviews of interventions. Chichester: Wiley-Blackwell; 2009.

53. Veroniki AA, Jackson D, Viechtbauer W, Bender R, Bowden J, Knapp G, et al. Methods to estimate the between-study variance and its uncertainty in meta-analysis. Research Synthesis Methods. 2016;7:55-79. doi:10.1002/jrsm.1164.

54. Higgins JPT, Green S. Cochrane Handbook for Systematic Reviews of Interventions 5.1.0 [updated March 2011], Chap. 9.6.5.1 2011. 2011.

55. Crawford MJ, Thana L, Methuen C, Ghosh P, Stanley SV, Ross J, et al. Impact of screening for risk of suicide: randomised controlled trial. Br J Psychiatry. 2011;198:379-84.

56. Gould MS, Marrocco FA, Kleinman M, Thomas JG, Mostkoff K, Cote J, Davies M. Evaluating iatrogenic risk of youth suicide screening programs: a randomized controlled trial. JAMA. 2005;293:1635-43.

57. Mathias CW, Michael Furr R, Sheftall AH, Hill-Kapturczak N, Crum P, Dougherty DM. What's the harm in asking about suicidal ideation? Suicide Life Threat Behav. 2012;42:341-51.

58. Teismann T, Forkmann T, Glaesmer H. Risikoabschätzung bei suizidalen Patienten: Geht das überhaupt? Verhaltenstherapie. 2019;29:804.

59. American Psychiatric Association. Diagnostic and statistical manual of mental disorders - Edition Fifth. Am Psychiatric Assoc. $2013 ; 21$.

60. Böttche, M., Kampisiou, K, Stammel, N., El-Haj-Mohamad, R., Heeke, C, Burchert, S, Heim, E., Wagner, B., Renneberg, B., Böttcher, J., Glaesmer, H., Gouzoulis-Mayfrank, E., Zielasek, J., Konnopka, A., Murray, L, Knaevelsrud, C. From formative research to cultural adaptation of a face-to-face and internet-based cognitive-behavioural intervention for Arabic-speaking refugees in Germany. under review.

\section{Figures}




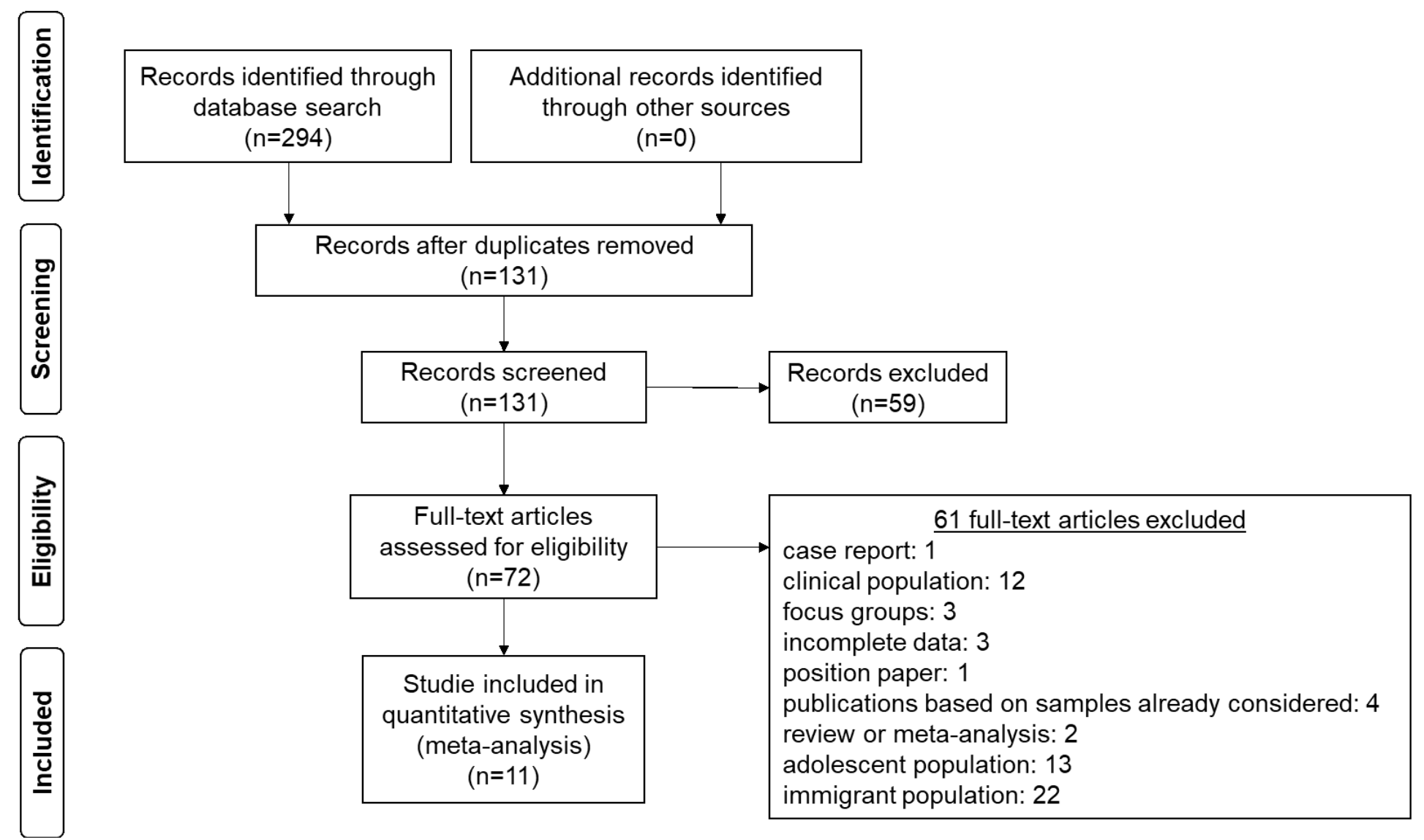

Figure 1

Flow diagram to reconstruct study selection

Study

Akinyemi et al. (2015)

Bhui et al. (2003)

Cochran et al. (2013)

Führer et al. (2016)

Leiler et al. (2019)

Meyerhoff et al. (2020)

Nickerson et al. (2019) refugees with secure visa

Nickerson et al. (2019) asylum seekers

\section{Random effects model}

Heterogeneity: $I^{2}=98 \%, \chi_{7}^{2}=308.61(p<0.01)$

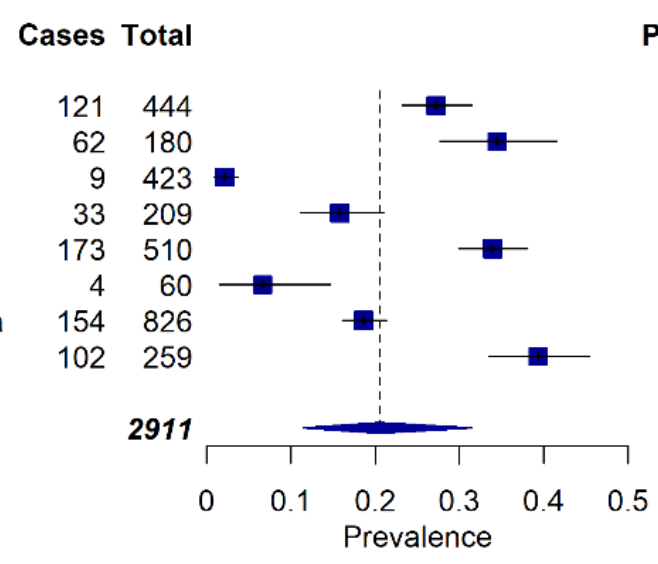

\section{Proportion}

$0.2725[0.2321 ; 0.3150]$

0.3444 [0.2766; 0.4156]

$0.0213[0.0094 ; 0.0375]$

$0.1579[0.1114 ; 0.2107]$

$0.3392[0.2987 ; 0.3809]$

$0.0667[0.0147 ; 0.1464]$

$0.1864[0.1606 ; 0.2138]$

$0.3938[0.3351 ; 0.4541]$

$0.2054[0.1140 ; 0.3150]$
$12.7 \%$

$12.4 \%$

$12.7 \%$

$12.5 \%$

$12.8 \%$

$11.5 \%$

$12.8 \%$

$12.6 \%$

\section{Figure 2}

Forest plot on the prevalence of suicidal ideation $(n=8)$

\section{Figure 3}

Forest plot on the prevalence of suicidal ideation in women $(n=5)$ 


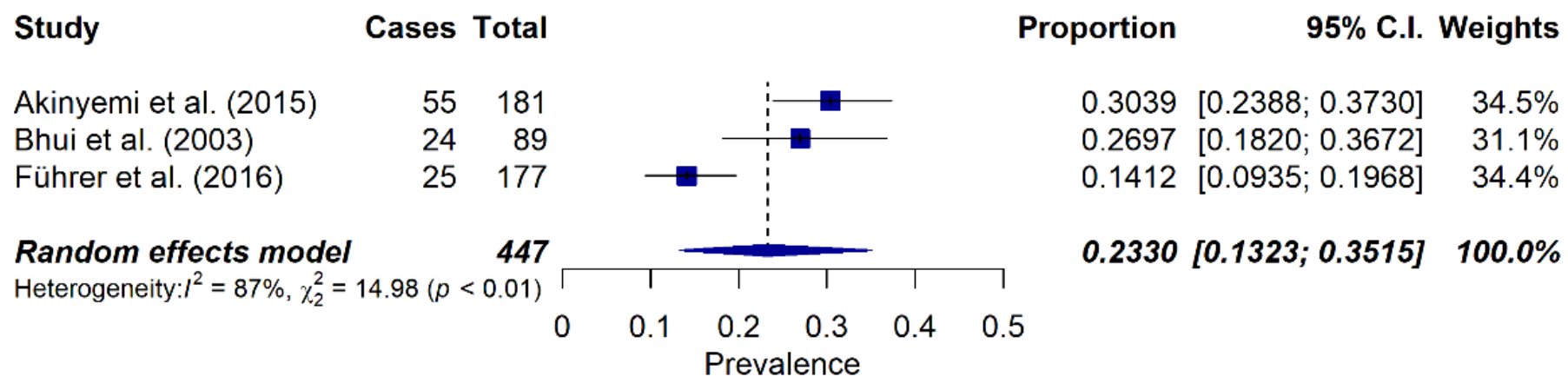

Figure 4

Forest plot on the prevalence of suicidal ideation in men $(n=3)$

Study

Cases Total

Alley (1982)

Cochran et al. (2013)

Meyerhoff et al. (2020)

Sohn et al. (2019)

Random effects model

Heterogeneity $: l^{2}=81 \%, \chi_{3}^{2}=15.87(p<0.01)$

1
$64192+$
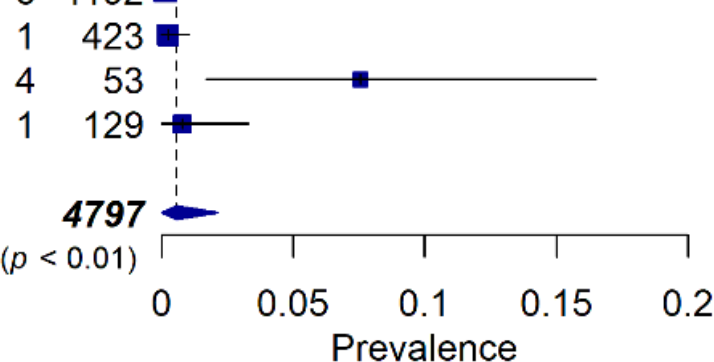

Proportion $\quad 95 \%$ C.I. Weights

$0.0014[0.0005 ; 0.0028] \quad 35.0 \%$

0.0024 [0.0000; 0.0101$] \quad 29.7 \%$

$0.0755[0.0168 ; 0.1650] \quad 13.8 \%$

$0.0078[0.0000 ; 0.0330] \quad 21.5 \%$

$0.0057[0.0000 ; 0.0214] \quad 100.0 \%$

Figure 5

Forest plot on the prevalence of suicide attempts $(n=4)$

\section{Supplementary Files}

This is a list of supplementary files associated with this preprint. Click to download.

- Appendix.docx 